\title{
Gorbachev needs an answer
}

Mr Mikhail Gorbachev's visit to London last week has sharpened still further the issue of NATO's tactical nuclear weapons. NATO cannot pretend that the issue is technical and exclusively its own concern.

LAST year's tragic earthquake in Armenia has cast a long shadow. That is the simplest explanation why Mr Mikhail Gorbachev's visit to London last week was probably as much a disappointment for him as for many of those who heard what he had to say. His original plan had been to follow his speech at the United Nations in December, when he made public his plan unilaterally to cull 500,000 people from the Soviet armed services, by travelling to Cuba and then to London. Then, in the interregnum between the Reagan and Bush administrations in Washington, it would have been easier for him to open a fruitful dialogue on arms control. By last week, the momentum had been dissipated. Worse, the British government, now preoccupied with the sharpening dispute within the North Atlantic Treaty Organization (NATO) about the continuing role of nuclear weapons in Europe, was in no mood to respond imaginatively.

The issue is simple, but none the less corrosive on that account. The treaty on missiles of intermediate range (INF) signed at the end of 1987 regulates the removal from Europe of missiles capable of carrying nuclear warheads a distance of $1,500 \mathrm{~km}$ or more, but only implicitly regulates missiles of shorter range. (A precondition of INF was the readiness of NATO and the Warsaw Pact to remove tactical nuclear weapons from the scene.) Now, NATO wishes to improve ("modernize") the performance of its tactical nuclear weapons over the next few years. Specifically, there is a plan for replacing the Lance missiles now sited in West Germany with improved rockets capable of travelling $500 \mathrm{~km}$. The Soviet Union disapproves - Gorbachev said so plainly last Friday. So, for different reasons, does West Germany.

Gorbachev's view is that improving the performance of NATO's tactical weapons will break the spirit if not the letter of INF. He said last week that if NATO goes ahead with its planned modernization, the talks on the regulation of conventional arms now under way in Vienna will be jeopardized. NATO's counter-argument is that nuclear weapons remain a necessary part of the defence of Western Europe. At least so long as the intended agreement on conventional forces in Europe remains in the future, nuclear weapons may be the only way of halting an armed incursion. That view is not new: NATO has held to the same doctrine for a quarter of a century. The novelty is twofold - there is now a chance of winning an agreement on conventional forces, while West German voters and thus, perforce, the West German government are increasingly attracted by the even brighter prospect of a more general disappearance of political and military tension in Europe.

Formally, so far as NATO is concerned, the issue is intended to be settled in the summer of this year, after the Bush administration's review of its security interests (and the associated defence budget) is complete. But that is more than NATO's managers can reasonably expect. If anything, the reluctance of West German voters to support governments which agree to give house-room to modernized weapons is more likely to grow than to melt away. A further difficulty is that the Vienna negotiations will not make sense if aircraft and other remote means of delivering bombs (nuclear or otherwise) are excluded, which is what NATO asks.

That is why the need now is for a constructive compromise. Gorbachev's protest that NATO's insistence on improved nuclear weapons in Europe would jeopardize the Vienna negotiations was quickly countered, in London and Washington, by a simple reiteration of the need to modernize outdated nuclear weapons. Why not, instead, acknowledge that the need for battlefield nuclear weapons in Europe would be diminished if the Vienna talks succeed, and thus make the planned changes contingent on failure at Vienna? That way, Gorbachev and his counterparts in the West could be saying much the same thing, while the important negotiation at Vienna would be invested with a sense of urgency.

\section{Disorderly publication}

There is no reason why discoveries should not first be published in daily newspapers, but there are drawbacks.

THE great fuss about cold fusion over the past few weeks raises important questions about the scientific literature and its function to which the scientific community should give urgent thought. Reports that nuclear fusion had been brought about in an electrochemical cell first appeared in two financial newspapers - the Wall Street Journal and the Financial Times - on 23 March. Professors Martin Fleischmann (Southampton) and Stanley Pons (Utah) were reported to have accomplished fusion in an electrolytic cell.

Soon it also became known that a group at Brigham 